\title{
TIPOLOGI ATAP PADA ARSITEKTUR VERNAKULAR DI SUMATERA SELATAN
}

\author{
Zuber Angkasa Wazir \\ Teknik Arsitektur Fakultas Teknik, Universitas Muhammadiyah Palembang \\ Jl. Jendral A. Yani. 13 Ulu Palembang \\ *Email: zuberpalembani@gmail.com
}

\begin{abstract}
The development of new urbanism paradigm in the world today, has been reminded of the importance of vernacular architecture in urban planning.. It would be advantageous for areas with high ethnic diversity as South Sumatra. This study aims to inventory the vernacular house typology in South Sumatra. Methods of study is to examine the vernacular houses of all ethnicities in South Sumatra (29 ethnicity) plus two ethnic from neighboring provinces (Kubu and Lambak). The study found 18 different types of houses, and also found that the typology of the roof consists of a limas roof, pelana roof, and a perisai roof. The variety of roof reflects the high ethnic mobilization in South Sumatra. Even so, as a result of acculturation that occurs in these dynamics, the variety is found only on the shape of the roof, while the other part of the building does not have a clear marker of difference. Implications of the New Urbanism presented in the design of contemporary urban planning in South Sumatra.
\end{abstract}

Keywords: arsitektur vernakular, Sumatera Selatan, tipologi bentuk, tipologi atap, keanekaragaman etnik.

\section{PENDAHULUAN}

Bangunan didefinisikan sebagai "wujud fisik hasil pekerjaan konstruksi yang menyatu dengan tempat kedudukannya, sebagian atau seluruhnya berada di atas dan/atau di dalam tanah dan/atau air" (Undang-undang RI No 28 tahun 2002). Sebagai bagian dari habitat manusia, bangunan memiliki fungsi yang melayani berbagai kebutuhan manusia dari yang paling dasar hingga kebutuhan tersier dengan fungsi utama sebagai tempat manusia melakukan kegiatannya. Hal ini mencakuplah fungsi sebagai hunian atau tempat tinggal, kegiatan keagamaan, kegiatan usaha, kegiatan sosial budaya, maupun kegiatan khusus.

Karena merupakan elemen penting dari suatu budaya, bangunan memiliki variasi yang sangat tinggi, tergantung pada budaya dan periode perkembangan. Bangunan tipe modern yang dikembangkan secara terstandar saat ini pada dasarnya adalah hasil dari pengembangan aspek-aspek tertentu tradisi adat (vernakular) Barat, dalam hal pembebasan atas kendala lingkungan dan estetika artifisialitas yang kongruen (Glassie, 1990). Sayangnya, hal ini membawa pada kendala interaksi sosial, kompartementalisasi fungsi dalam suatu bangunan, dan imposisi simetrikalitas eksternal yang dipaksakan [2]. Sementara hal ini memang mendukung sifat individualitas dan fungsionalitas pada masyarakat perkotaan, hal ini juga sekaligus menciptakan keterasingan manusia sebagai mahluk sosial dan memberikan risiko tersendiri jika dihubungkan dengan karakteristik lokal yang berbeda-beda dalam hal sifat lingkungan alami maupun risiko tersendiri yang dapat dihasilkan oleh bangunan modern tersebut (misalnya risiko kebakaran). Hal ini semua tidak ditemukan pada arsitektur vernakular yang mengintegrasikan aspek lingkungan dan sosial sekaligus dalam proses maupun desain akhirnya.

Selain itu, bangunan vernakular memiliki fungsi identitas di masa modern ini. Pada era globalisasi saat ini, identitas kultural menjadi semacam hal berharga dalam upaya mengangkat daya saing antar budaya. Identitas yang diberikan oleh bangunan vernakular menyediakan habitus spasial bagi suatu budaya atau kelompok masyarakat tertentu yang mencirikan karakteristik kultural dasar mereka. Hal ini semakin penting ketika pembangunan yang berkelanjutan dan bertanggungjawab 
menjadi sebuah wacana penting dalam pembangunan suatu kawasan seperti perkotaan. Karenanya, desain kota yang disusun oleh bangunan-bangunan vernakular bukan saja memberikan manfaat sosiologis dan lingkungan, tetapi juga mendukung identitas kota yang memungkinkan pariwisata berkembang lebih pesat.

Semangat kembali ke arsitektur vernakular, yang diusung oleh urbanisme baru, merupakan semangat baru yang muncul di Indonesia dewasa ini. Era otonomi daerah yang berjalan sejak tahun 1999 memberikan kesempatan bagi pemerintah daerah untuk mengembangkan identitas-identitas kedaerahan mereka, termasuk arsitektur vernakular, pada dimensi yang lebih luas lagi. Pada faktanya, hampir setiap kabupaten di luar Jawa memiliki identitas rumah adat sendiri. Hal ini apalagi didukung oleh keanekaragaman budaya yang sangat tinggi di Indonesia, dengan hampir masing-masingnya mampu berkontribusi bagi pengembangan arsitektur vernakular komposit yang menawarkan aspek-aspek unggul dari masing-masing budaya keruangan etnik yang ada di satu daerah (kabupaten/kota atau provinsi).

Sumatera Selatan merupakan salah satu daerah dengan keanekaragaman etnik yang cukup tinggi di Indonesia. BPS menghitung terdapat 29 suku yang memiliki asal dari Sumatera Selatan (BPS, 2011). Kawasan ini merupakan salah satu kawasan tertua di Indonesia sebagai tempat dari imperium Sriwijaya (abad ke-6 M) berdiri. Kota Palembang sendiri merupakan kota tertua di Indonesia (dari 97 kota yang ada di Indonesia) dengan tahun pendirian 682 M. Sungguh demikian, tata kota yang berlaku saat ini masih belum menunjukkan karakteristik sesungguhnya dalam adopsi arsitektur vernakular. Prijotomo (1996) pernah melakukan penelitian evolusi arsitektur di Indonesia dalam satu abad (1890-an - 1990-an) untuk melihat bagaimana arsitektur Barat mempengaruhi arsitektur lokal dan begitu pula sebaliknya. Terlihat bahwa arsitektur Belanda dan rumah modern Indonesia telah dipengaruhi cukup kuat oleh budaya vernakular lokal. Sungguh demikian, dalam kajiannya tidak muncul pengaruh dari bangunan vernakular Sumatera Selatan dalam perkembangan arsitektur nasional. Hal ini patut disayangkan dengan adanya sejarah panjang masyarakat di Sumatera Selatan. Setidaknya, diharapkan kalau aspek-aspek vernakular dapat diwujudkan dalam urbanisme baru di kawasan Kota Palembang sendiri sebagai ibukota dari Sumatera Selatan. Karenanya, penelitian ini berupaya meninjau bangunan-bangunan vernakular di Sumatera Selatan sebagai kontribusi yang penting untuk pengembangan kota Palembang yang berperspektif urbanisme baru dan berpotensi memberikan kontribusi yang lebih luas pada tataran nasional dalam pengembangan bentuk rumah vernakular maupun penempatannya dalam kerangka budaya nasional.

\section{State of The Art}

Sejumlah literatur telah membahas mengenai aspek-aspek tipologis dari arsitektur vernakular di Sumatera Selatan. Sumintardia (1974) misalnya, telah melakukan survey rumah-rumah tradisional di Palembang. Survey yang lebih luas dilakukan oleh Alimansyur et al [6] terkait arsitektur tradisional daerah Sumatera Selatan. Terakhir, Schefold [7] bahkan telah melakukan survey pada semua rumah vernakular di Indonesia, termasuk rumah-rumah di Sumatera Selatan.

Artikel ini menyediakan kerangka dasar untuk eksplorasi yang lebih terkini mengenai bangunan vernakular di Sumatera Selatan dengan fokus pada bangunan untuk rumah tinggal sekaligus kemungkinan penerapannya dalam urbanisme baru. Urbanisme baru pada dasarnya adalah "strategi perencanaan ruang yang bertujuan mencipta ulang persekitaran dan masyarakat yang ditemukan dalam permukiman lama sebelum munculnya permukiman kumuh, jalan raya, dan perumahan massal" [8]. Dengan adanya tipologi rumah vernakular di Sumatera Selatan, diharapkan hasil yang diperoleh mampu digunakan untuk mendesain persekitaran dan masyarakat di kota-kota yang berkembang di Sumatera Selatan ke arah Urbanisme Baru yang menghargai dan mengembalikan karakterkarakter lokal pada pembangunan fisik, khususnya pada bangunan rumah tinggal dan perkantoran.

\section{Urbanisme Baru}

Urbanisme baru merupakan gerakan arsitektur dan perencanaan wilayah yang mendorong pengembangan desain berbasis bentuk urban tradisional dalam pengembangan arsitektur, mulai dari skala bangunan hingga skala urban. Prinsip-prinsip yang dipegang oleh urbanisme baru adalah pengembangan kawasan yang beranekaragam, kompak, digunakan secara bercampur, berorientasi pejalan kaki, dan 
bersahabat dengan transit. Hal ini dinyatakan dapat memecahkan masalah perkotaan modern yang dipenuhi oleh permukiman suburban yang kumuh dan penurunan kualitas hidup di bagian dalam kota, dimana masyarakat terkotakkotakkan dan saling menghindari satu sama lain. Urbanisme Baru menekankan bahwa desain kota harus menekankan pada pentingnya aspek-aspek publik ketimbang aspek-aspek privat (Groat, L. N., \& Wang, D. (2013)).

Urbanisme baru kemudian segera dipandang sebagai fenomena arsitektur Amerika terbesar setelah era Perang Dingin. Prinsipprinsip urbanisme baru telah diterapkan dalam berbagai bidang seperti perlindungan lingkungan, preservasi historis, perencanaan transit, pedestrian, dan bersepeda, pembangunan berkelanjutan, manajemen pertumbuhan, program jalan utama, dan pertumbuhan cerdas perkotaan (Bohl, 2000).

Sejumlah karakteristik dari urbanisme baru antara lain:

1. Mengembangkan lewat pencampuran tipe satuan rumah, sehingga terdapat blok berpendapatan rendah bertetangga dengan blok berpendapatan tinggi dalam suatu hubungan yang harmonis, ketimbang mengkotak-kotakkan rumah miskin dan kaya di tempat-tempat tertentu di kota (Hipp, J. (2010).

2. Pola perkembangan berbasis ekologi dan teknologi, dengan penekanan pada sistem konektivitas kendaraan dan pejalan kaki antar permukiman dilengkapi dengan pemandangan alamiah dan akses bersama pada suatu pusat yang menawarkan berbagai fasilitas publik seperti sekolah, rumah ibadah, pasar, dan taman (Ercoskun, O. Y., 2009).

3. Fungsi utama kota bukan sebagai pusat perdagangan tetapi sebagai pusat permukiman sehingga penekanan pada permukiman harus diberikan dengan menyorot pada arsitektur vernakular dan aspek-aspek historisitas perkotaan (Jacoby, S., 2013).

\section{Hubungan antara Urbanisme Baru dan Arsitektur Vernakular}

Prinsip-prinsip urbanisme baru menunjukkan relevansi yang kuat pada arsitektur vernakular. Prinsip orientasi pada pejalan kaki misalnya, memfasilitasi arsitektur vernakular karena arsitektur vernakular cenderung menggunakan lahan untuk kepentingan pejalan kaki ketimbang kendaraan. Lebih dari itu, karena arsitektur dipandang berorientasi pada lokalisasi, maka urbanisme baru mencari otentisitas pada bangunan vernakular untuk menghasilkan panduan, pola, dan tipologi bangunan yang dapat diterapkan di lapangan (Ellis, C., 2002). Urbanisme baru menjadi tradisi yang bersahabat dengan upaya pembangunan kawasan yang menghargai tradisi historik dan arsitektur vernakular (Bettencourt, L. M., 2013).

Tipologi bentuk bangunan yang dipilih agar sejalan dengan urbanisme baru adalah tipologi atap. Tipologi atap sesuai karena paling mudah diterapkan dalam suatu desain urbanisme baru, mengingat bentuk ini relatif independen dengan bagian struktur aksesibilitas dan perumahan yang ada di permukaan tanah. Selain itu, atap memungkinkan untuk diamati secara menyeluruh dari perspektif bawah sehingga menonjol dan menunjukkan aspek vernakular secara tegas. Agar lebih menonjol, sebenarnya harus ada kajian proporsi sehingga proporsi atap setiap rumah vernakular terhadap bagian bawah bangunan dapat ditentukan dan menunjukkan aspek vernakular yang lebih jelas. Hal ini dapat digunakan sebagai rekomendasi untuk penelitian selanjutnya.

\section{METODE PENELITIAN}

Penelitian ini bersifat deskriptif dan berusaha membangun tipologi bentuk bangunan vernakular di Sumatera Selatan. Metode yang digunakan adalah metode studi literatur dengan menggunakan mesin pencari Google untuk menemukan rumah tradisional etnik-etnik di Sumatera Selatan. Total terdapat 29 etnik asal Sumatera Selatan ditambah dengan dua etnik lain dari provinsi tetangga yang memiliki jumlah yang signifikan dalam populasi penduduk yaitu etnik Lambak dan Kubu. Tabel berikut mendaftarkan semua etnik di Sumatera Selatan dan rumah vernakular yang mewakilinya. 
Tabel 1. Arsitektur Vernakular Berdasarkan Etnik

\begin{tabular}{|c|c|c|c|}
\hline No & Etnik & Rumah & Keterangan \\
\hline 1 & Palembang & Rakit, Limas, Gudang, Panggung Air & $\begin{array}{l}\text { Kemungkinan digunakan suku-suku lainnya } \\
\text { di DAS Musi }\end{array}$ \\
\hline 2 & Daya & $?$ & $\begin{array}{l}\text { Berada di aliran Ogan, OKU, khususnya } \\
\text { Kecamatan Lengkiti. }\end{array}$ \\
\hline 3 & Enim & Limas & Variasi Bentuk Limas. \\
\hline 4 & Gumai & Limas & Variasi Bentuk Limas. \\
\hline 5 & Kayu Agung & Limas & Variasi Bentuk Limas. \\
\hline 6 & Kikim & Godong & $\begin{array}{l}\text { Bermukim di sekitar DAS Kikim, } \\
\text { Kabupaten Lahat. }\end{array}$ \\
\hline 7 & Kisam & Baghi, Limas & $\begin{array}{l}\text { Daerah Muara Dua, OKU, banyak kesamaan } \\
\text { dengan Pasemah }\end{array}$ \\
\hline 8 & Komering & Minanga, Komering, Limas & Suku Besar, terdiri dari sejumlah sub suku \\
\hline 9 & Lematang & Limas & Variasi Bentuk Limas. \\
\hline 10 & Lintang & Rumah Lintang, Limas & $\begin{array}{l}\text { Penduduk Mayoritas Kabupaten Empat } \\
\text { Lawang }\end{array}$ \\
\hline 11 & Lom & Rumah Lom & Etnik asal Bangka Belitung. \\
\hline 12 & Mapur & Rumah Lom & Mapur dan Lom adalah Sinonim. \\
\hline 13 & Sekak & Perahu Kolek, Panggung Air & $\begin{array}{l}\text { Etnik asal Bangka Belitung. Disebut juga } \\
\text { suku Sawang. }\end{array}$ \\
\hline 14 & Meranjat & Rumah Bongkar Pasang & $\begin{array}{l}\text { Disebut juga suku Penesak. Berada di } \\
\text { beberapa kecamatan di Ogan ilir. }\end{array}$ \\
\hline 15 & Musi Banyuasin & Pesirah & Wilayah Kabupaten Musi Banyuasin. \\
\hline 16 & Musi Sekayu & Rumah Rakit, Panggung Air, Limas & Sinonim dengan Sekayu. \\
\hline 17 & Sekayu & Rumah Rakit, Panggung Air, Limas & "Manusia Sungai" \\
\hline 18 & Ogan & Limas & Variasi Bentuk Limas. \\
\hline 19 & Orang Sampan & Perahu Kolek, Panggung Air & $\begin{array}{l}\text { Kemungkinan sama dengan Orang Laut di } \\
\text { Riau. }\end{array}$ \\
\hline 20 & Pasemah & Baghi, Limas & Wilayah Pasemah. \\
\hline 21 & Pedamaran & Rakit, Panggung Air & Kecamatan Pedamaran, Kabupaten OKI [16] \\
\hline 22 & Pegagan & Limas & $\begin{array}{l}\text { Bermukim di Kelurahan Tanjung Raja Barat, } \\
\text { Kabupaten Ogan Ilir }\end{array}$ \\
\hline 23 & Rambang & Limas & Terkenal dengan Limas 100 Tiang. \\
\hline 24 & Ranau & Lamban Tuha & Wilayah Ranau. \\
\hline 25 & Rawas & Limas & $\begin{array}{l}\text { Umumnya petani. Bermukim di dekat } \\
\text { Sungai Rawas. }\end{array}$ \\
\hline 26 & Saling & $?$ & $\begin{array}{l}\text { Aliran Sungai Saling, Kecamatan Saling, } \\
\text { Kabupaten Empat Lawang }\end{array}$ \\
\hline 27 & Semendo & Tunggu Tubang, Limas & Variasi Bentuk Limas. \\
\hline 28 & Teloko & $?$ & $\begin{array}{l}\text { Bermukim di sekitar Lebak Besar/Danau } \\
\text { Teloko, OKI }\end{array}$ \\
\hline 29 & Ulu & Potong Jang & Rumah Khas Ulu. \\
\hline 30 & Lambak & Tua Bubungan Lima & Etnik asal Bengkulu. \\
\hline 31 & Kubu & Godong & Etnik asal pedalaman Jambi. \\
\hline
\end{tabular}

Etnik ini mencakuplah etnik Lembak dari Bengkulu dan etnik Kubu dari Jambi. Karenanya, total terdapat 31 etnik yang diperiksa. Kata kunci yang digunakan adalah "(Nama etnik) house" atau "(nama etnik) traditional house". Tidak semua etnik memiliki rumah adat yang terdokumentasi (Teloko, Saling, Daya) dan terdapat banyak etnik yang memiliki rumah adat dari jenis yang sama, khususnya rumah limas dan panggung air.

\section{HASIL DAN PEMBAHASAN}

Tipologi bentuk atap rumah secara umum adalah limas, pelana, dan perisai.

\section{Atap Limas}

1. Rumah Limas/Rumah Bari

Rumah limas berfungsi sebagai tempat tinggal sekaligus perayaan. Rumah limas berbentuk panggung persegi panjang (Gambar 1). Rumah ini dikatakan limas karena memiliki atap berbentuk piramida terpenggal (limas). Karakteristik lain adalah 
lantai rumah memiliki ketinggian yang tidak sama. Terdapat tiga bagian dari lantai yang mencakup bagian depan (beranda), tengah (pusat rumah), dan bagian belakang untuk tempat tinggal anak dan dapur (Siswanto; Salim; Dahlan; Hariza, 2013). Rumah umumnya diukir secara halus dengan pintu dan jendela memiliki bukaan ke atas (lawang kipas) (Diem, 2004). Bagian depan rumah tidak berjendela sementara diantara kedua pintu depan terdapat dinding ruji-ruji kayu (Zulfikri, 2004). Rumah ini banyak ditemukan di daerah Palembang hingga Kabupaten OKU. Rumah ini umumnya cukup besar dengan karakteristik fisik kuat. Rumah ini adalah generasi kedua dari tipe rumah di Palembang setelah Rumah Rakit (Ardiansyah, 2011).

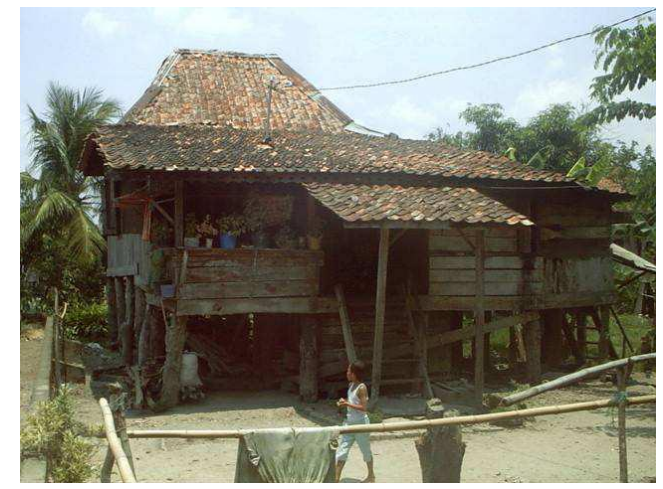

Gambar 1. Rumah Limas/Bari

Sumber: Murod, dkk, 2002

\section{Rumah Gudang}

Rumah gudang adalah generasi ketiga dari rumah di Palembang (Gambar 2). Rumah gudang berdiri di atas tiang dengan lantai rumah berketinggian sama. Bagian bawah rumah digunakan sebagai gudang. Lantai dari papan dan bentuk atap perisai, dengan penutup atap genteng atau seng (Diem, 2004). Rumah gudang tersebar di Palembang hingga ke OKU. Rumah gudang umumnya merupakan rumah pilihan masyarakat biasa. Kombinasi antara rumah limas dan rumah gudang disebut rumah limas gudang (Triyuly; Desfita; \& Tria, 2013). Rumah limas gudang hanya memiliki satu ketinggian lantai.

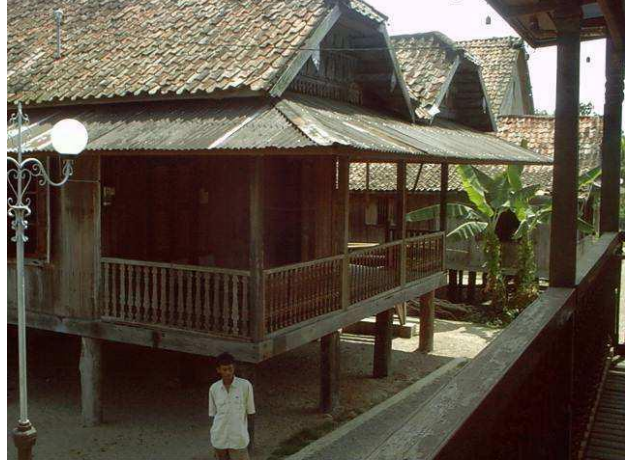

Gambar 2. Rumah Gudang

Sumber: Murod, dkk, 2002

3. Rumah Lamban Tuha

Rumah tipe ini banyak ditemukan di kabupaten OKU sebagai rumah dari masyarakat Ranau yang merupakan sub etnik dari suku Komering (Gambar 3). Atap memiliki kemiringan 45 derajat dengan penutup atap seng sementara dinding ruang bawah ditutup oleh daun nipah horizontal. Kaki bangunan menggunakan struktur unik berupa sistem Ari dan Kalindang. Sistem Ari adalah tiang penyangga yang bertumpu pada balok kayu horizontal ditempatkan di atas tanah sementara sistem Kelindang berupa penumpuan beban rumah pada susunan balok kayu yang ditumpuk horizontal. Sistem ini membuat rumah Lamban Tuha tergolong tahan gempa (Siswanto; Salim; Dahlan; Hariza, 2013).

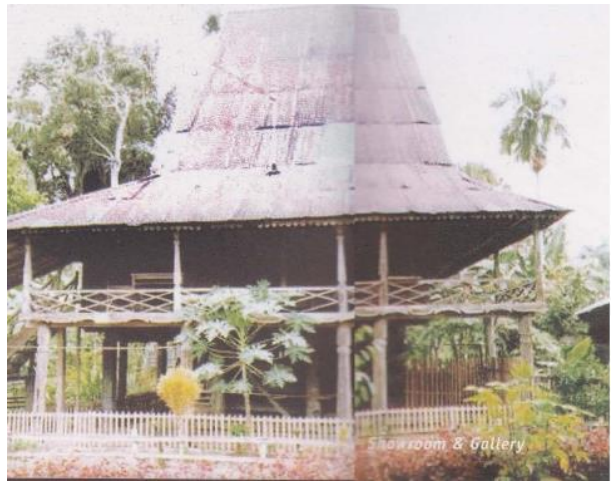

Gambar 3. Rumah Lamban Tuha Sumber: Fransiska dan Setiawan, 2006

4. Rumah Pesirah

Rumah ini merupakan rumah besar dari kabupaten Musi Banyuasin (Gambar 4). Atap berbentuk campuran limas dan pelana, tetapi pada dasarnya adalah limas. Teras tedapat di kedua samping bangunan, begitu pula pencapaian. 


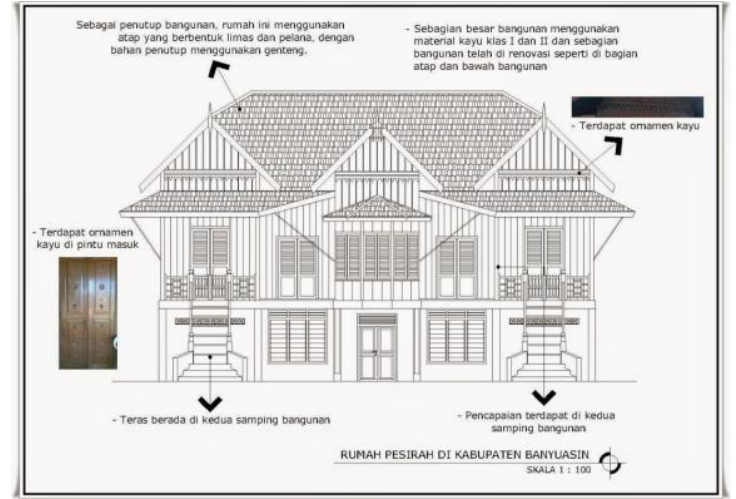

Gambar 4. Rumah Pesirah

Sumber: Anonim, 2014

\section{Rumah Lintang}

Rumah Lintang adalah rumah dari suku Lintang, suku mayoritas di Kabupaten Empat Lawang (Gambar 5). Karakteristik rumah Lintang adalah panggung dengan empat ruang utama yaitu:

a. Ruang depan, terdiri dari kamar bujang dan ruang untuk berkumpul bujang.

b. Ruang tamu utama, untuk menerima tamu dan berkumpul keluarga.

c. Ruang tengah, mencakup kamar tidur anak gadis dan orang tua.

d. Ruang belakang, mencakup dapur, ruang makan, dan tempat mencuci (Gaghang) (Majid, 2008).

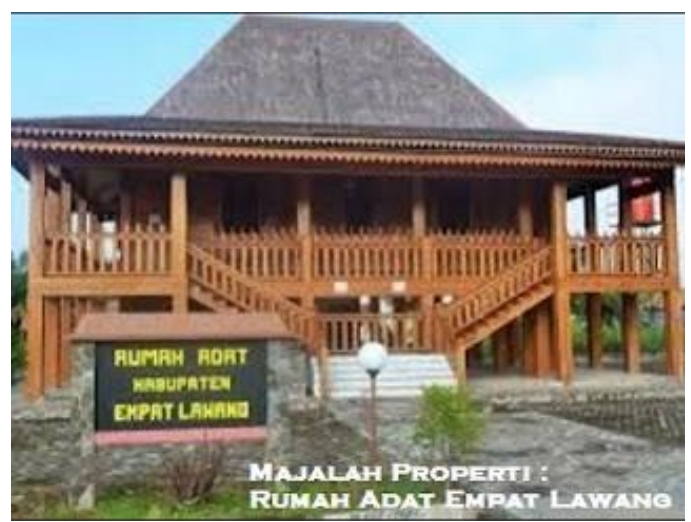

Gambar 5. Rumah Lintang

Sumber: Rumah Perumahan, 2016

6. Rumah Tua Bubungan Lima

Rumah tradisional dari etnik Lembak yang bermukim di hulu Sungai Musi hingga ke Bengkulu (Gambar 6). Rumah ini berbentuk panggung dengan ruangan-ruangan besar. Kolong rumah digunakan untuk menyimpan kayu bakar (sulang kayu) sementara pekarangan tidak memiliki pagar pembatas. Atap berbentuk limas.Tiang sering dilapisi batu.

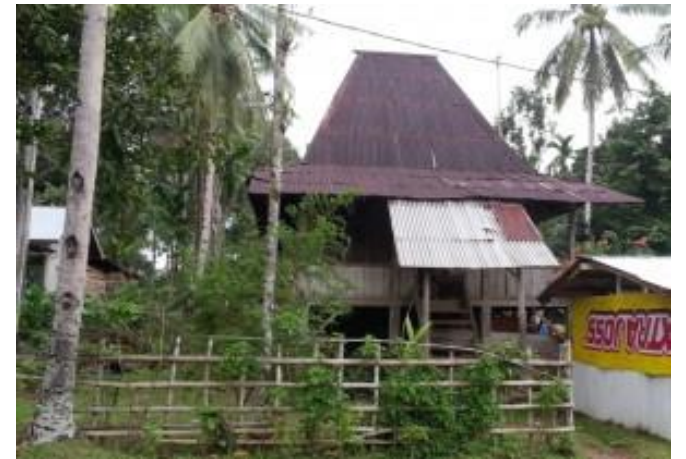

Gambar 6. Rumah Tua Bubungan Lima Sumber: Harian Rakyat Bengkulu, 2015

\section{Atap Pelana}

1. Rumah Rakit

Rumah rakit merupakan rumah terapung yang banyak ditemukan di Sungai Musi (Gambar 7). Rumah rakit selalu terapung di atas air sehingga praktis berada di badan sungai (Hidayat, 2014). Rumah terapung ini menggunakan susunan balok kayu atau bambu dengan lantai bahan papan. Atap berbentuk pelana datar dengan penutup dari daun nipah, alang, atau ijuk, diikat dengan tali dari rotan. Varian dengan bentuk pelana yang lebih melengkung disebut Rumah Rakit Tionghoa. Bagian ujung pelana diperkuat dengan sistem konstruksi Tionghoa karena rumah ini pada awalnya memang dibuat oleh etnik Tionghoa yang sempat dilarang untuk tinggal di daratan (Diem, 2004). Rumah ditempatkan sejajar dengan tepian sungai dan tersusun berderet ke arah daratan. Rumah yang berada paling ke arah sungai umum digunakan untuk berdagang sementara rumah yang lebih ke darat disebabkan karena penghuni rumah bekerja di darat (Diem, 2004). Bangunan ini berfungsi sebagai tempat tinggal, warung, bengkel, dan sebagainya. Bagian depan rumah dapat difungsikan untuk tempat mencari ikan.

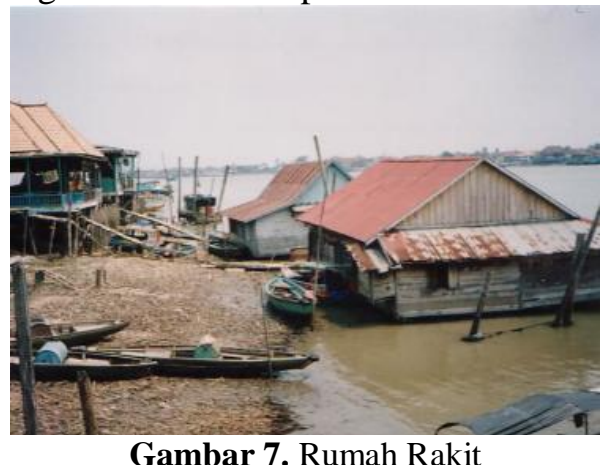

Gambar 7. Rumah Rakit

Sumber: Amin, 2013 
2. Rumah Ulu

Rumah Ulu sebenarnya lebih pantas dipandang sebagai kelompok dari beberapa jenis rumah karena istilah Ulu itu sendiri adalah penanda lokasi hulu sungai Musi dan di lokasi ini terdapat banyak etnik. Karakteristik umum dari rumah ulu memiliki bentuk dasar segi empat. Sebagian ruangan memiliki plafond (pagu hantu) untuk menyimpan barang dan makanan. Sementara itu atap berbentuk pelana, bukannya limas. Atap pelana ini menjorok ke depan dan ke belakang pada bagian tengahnya. Rumah berbentuk panggung untuk menghindari musim pasang dan biantang buas. Hanya ada satu tangga terletak di depan rumah dan beranak tangga ganjil (Saganta, J., Imron, A., $\&$ Arif, S., 2014). Bagian atas untuk tempat tinggal dan bawah untuk penyimpanan alat rumah tangga.

Klasifikasi rumah Ulu ini antara lain:

a. Rumah Minanga

Rumah Minanga memiliki atap pelana persegi panjang. Rumah ini banyak digunakan oleh suku Komering (Gambar 8).

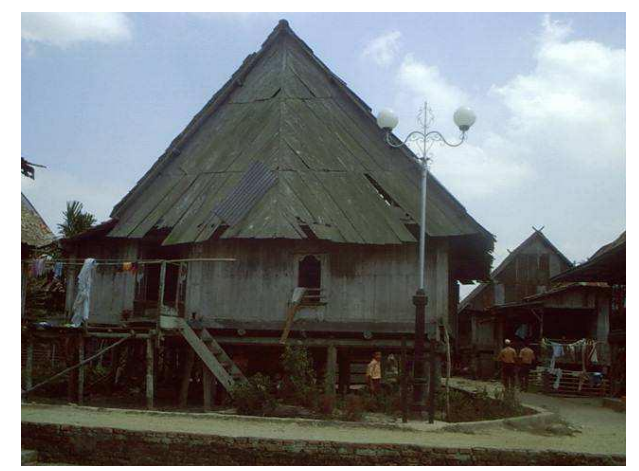

Gambar 8. Rumah Ulu Minanga

Sumber: Murod, C. dkk., 2002

b. Rumah Baghi

Rumah tipe ini berada di kawasan Pelang

Kenidai, Pagar Alam dan merupakan rumah dari suku Basemah/Pasma (Gambar 9). Rumah Baghi memiliki tiga tipe sesuai dengan status sosial pemilik. Tipe ini mencakup Rumah Tatahan yang memiliki ukiran halus, Rumah Kilapan yang tidak berukir, dan Rumah Padu Kingking yang mengkombinasikan kayu dan bambu. Atap secara umum berbentuk pelana trapesium dengan patahan pada bubungan. Kajian Rinaldi et al (Rinaldi, Z., Purwantiasning, A. W.,
\& Nur'aini, R. D., 2015) menyimpulkan kalau tipe rumah ini tergolong tahan gempa.

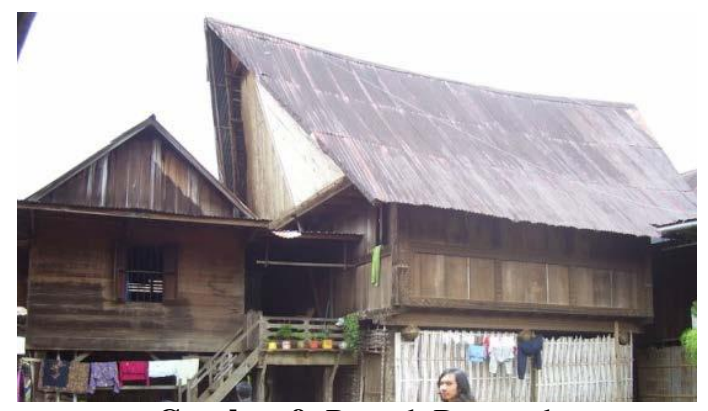

Gambar 9. Rumah Besemah

(Rinaldi, Z., Purwantiasning, A. W., \& Nur'aini, R. D., 2015)

c. Rumah Tunggu Tubang

Rumah ini banyak ditemukan di kawasan Pulau Panggung, OKI dan Muaraenim (Gambar 10). Rumah ini merupakan rumah etnik Semendo. Atap secara umum berbentuk pelana trapesium dengan patahan pada bubungan.

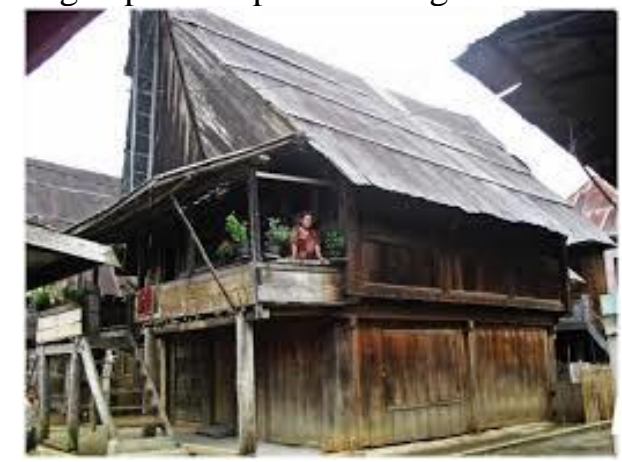

Gambar 10. Rumah Tunggu Tubang Sumber: Lensa Berita, 2015

d. Umeak Potong Jang

Rumah ini merupakan rumah yang dijadikan identitas dari kabupaten OKU (Gambar 11).

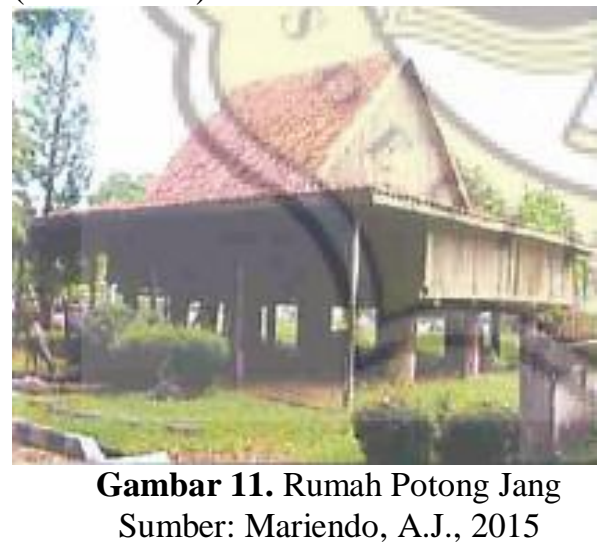


3. Rumah panggung atas air

Hunian vernakular khas kawasan pesisir dan tepi sungai di Asia tenggara adalah hunian panggung atas air (Gambar 12). Hunian tipe ini adalah rumah sederhana biasa dengan modifikasi bagian pondasi yang berupa bentuk panggung tinggi yang menancap di dasar air. Hunian tipe ini dapat ditemukan di sepanjang sungai-sungai besar di Sumatera Selatan dan Kalimantan, maupun di kepulauan sekitar Sulawesi Selatan dan Tenggara (khususnya etnik Bajau), dan juga dapat ditemukan di pesisir timur Teluk Benggala (etnik Moken), dan Kampung Ayer, Brunei. Di kawasan Sumatera Selatan, etnik yang paling banyak menggunakan rumah panggung atas air adalah Palembang, Pedamaran, dan Sekak di Bangka.

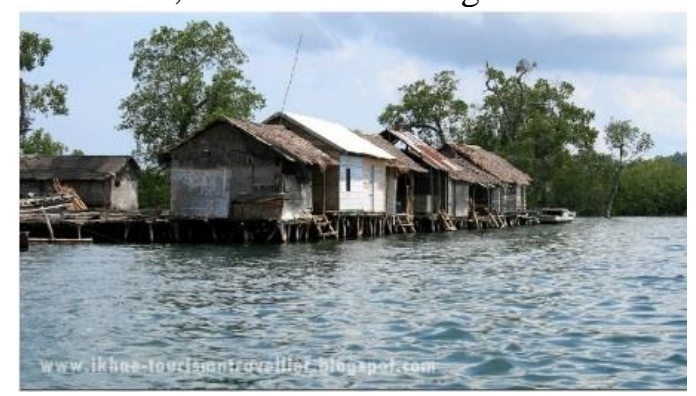

Gambar 12. Rumah Panggung Atas Air Milik Suku Sekak (Sawang)

Sumber: Ikhae, 2010

\section{Perahu Kolek}

Khusus bagi suku Sekak, diketahui bahwa sebagian dari mereka yang tidak memiliki tanah di darat, umumnya tinggal di atas perahu kolek, seperti halnya suku Anak Laut yang berada disekitar Kepulauan Riau atau suku Bajau di kawasan timur Indonesia. Perahu kolek juga digunakan sebagai hunian bagi etnik yang disebut "Orang Sampan" di Sumatera Selatan (Gambar 13). Sungguh demikian, hal ini semestinya lebih dilihat sebagai masalah kemiskinan ketimbang masalah budaya. Ketiadaan hak milik di darat memaksa mereka tinggal di dalam perahu dengan fasilitas seadanya. Rumahrumah perahu kolek ini dibangun sangat sederhana dengan tipe atap pelana.

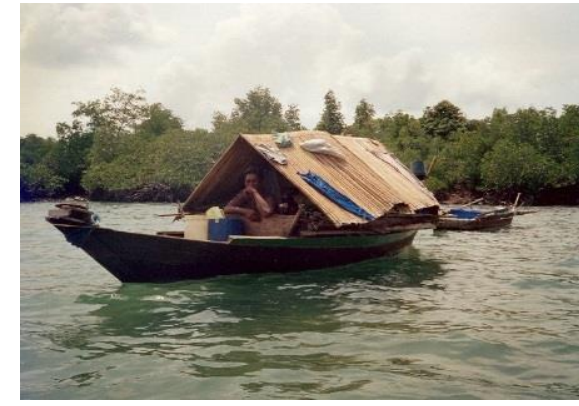

Gambar 13. Perahu Kolek

Sumber: Andaya, B.W., 2006

5. Rumah Lom

BPS mendaftarkan suku Lom sebagai suku asal Sumatera Selatan. Sebenarnya, suku Lom berasal dari kawasan Bangka, yang pada gilirannya memiliki asal usul dari Vietnam. Penempatannya dalam data BPS kemungkinan disebabkan provinsi Bangka Belitung pernah menjadi bagian dari provinsi Sumatera Selatan. Bentuk rumah suku Lom adalah panggung dengan atap rumbia dan dinding dari kulit pohon. Rumah berbentuk sangat sederhana (Gambar 14-16).

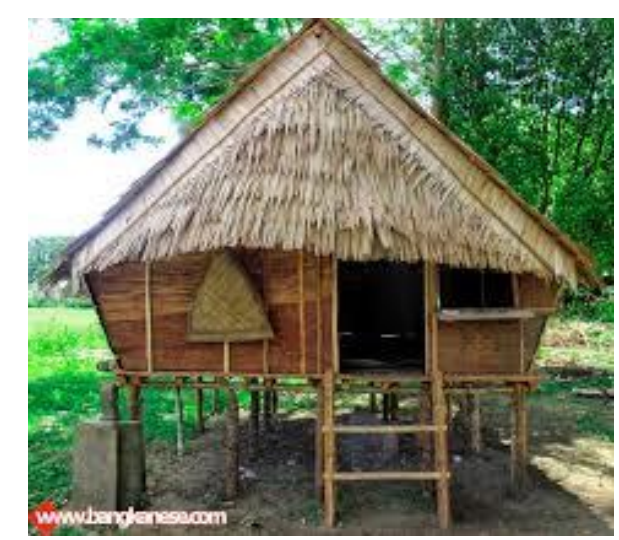

Gambar 14. Rumah Vernakuler Lom Sumber: Vau G., 2016

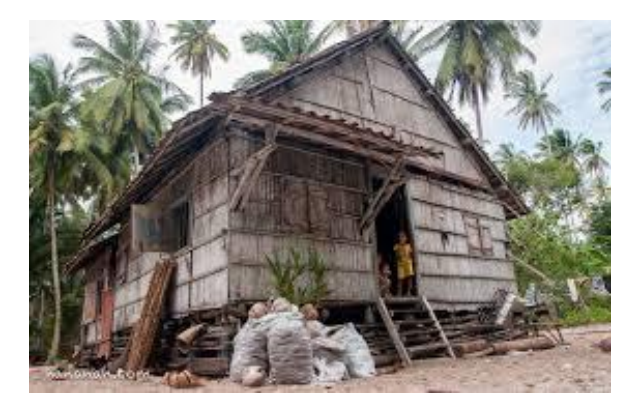

Gambar 15. Bentuk besar Rumah Vernakular Lom

Sumber: Sumber: Vau G., 2016 




Gambar 16. Balai Adat Lom

Sumber: Tribun News, 2014

6. Rumah Godong

Rumah godong adalah rumah dari suku Kubu (Anak Dalam) yang bermukim terutama di kawasan Jambi (Gambar 17). Rumah godong sangat sederhana karena dibangun hanya ketika membuka lahan atau menunggu panen. Bahan baku rumah Godong adalah kayu dan jerami untuk atap. Sementara paku digantikan dengan sistem ikat rotan. Rumah godong sendiri fungsinya lebih sebagai tempat penyimpanan atau menerima tamu sementara penduduk tidur di tanah (Rumah ditano) atau tenda (Susudung) dan tikar (Bolalapion) (Prasetijo, 2013). Bentuk rumah panggung dengan tinggi sekitar 1,2 meter. Karena bentuk yang sangat sederhana, rumah tipe ini kemungkinan digunakan secara umum pada suku-suku pedalaman perambah hutan di Sumatera, termasuk suku Kikim di DAS Kikim, Kabupaten Lahat.

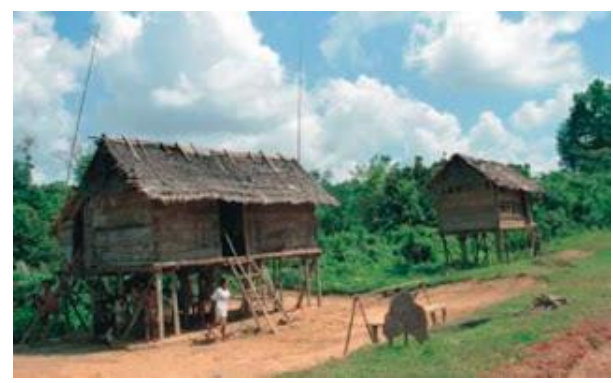

Gambar 17. Rumah Godong Sumber: Anonim, 2010

\section{Atap Perisai}

1. Rumah Rakit Pedamaran

Rumah rakit dalam bentuk besar dengan atap perisai banyak ditemukan di kawasan Pedamaran, Kecamatan Pedamaran, Kabupaten OKI (Gambar 18). Rumah-rumah suku Pedamaran ini memiliki proporsi atap yang sangat besar dibandingkan bagian bawah rumah. Di sisi lain, rumah tidak berbentuk panggung, tetapi langsung mengambang di atas air atau dengan tali tambang maupun tiang tersembunyi.

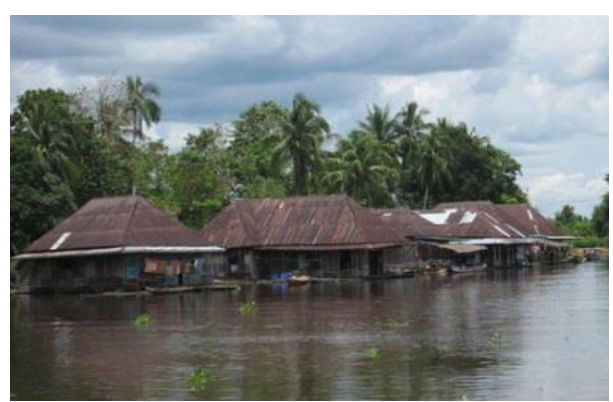

Gambar 18. Rumah Rakit Pedamaran Sumber: Utami, E., 2016

2. Rumah Komering

Rumah Komering memiliki bentuk Melayu dengan panggung tinggi. Rumah Komering banyak ditemukan di kawasan sekitar DAS Komering (Gambar 19).

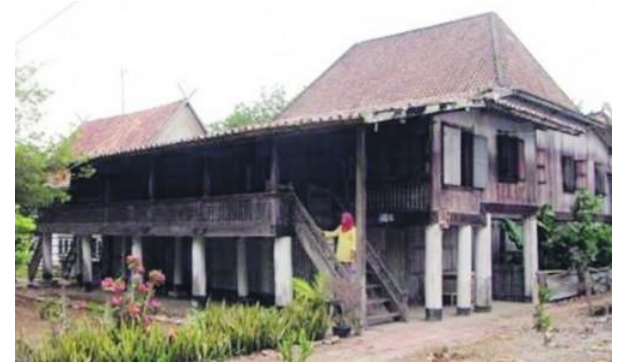

Gambar 19. Rumah Adat Suku Komering Sumber: Kaskus, 2015

3. Rumah Bongkar Pasang

Rumah ini ditemukan pada wilayah suku Penesak atau Meranjat, di kawasan Ogan Ilir, khususnya Kecamatan Tanjung Batu, Payaraman, Lubuk Keliat, dan Indralaya Selatan (Gambar 20).

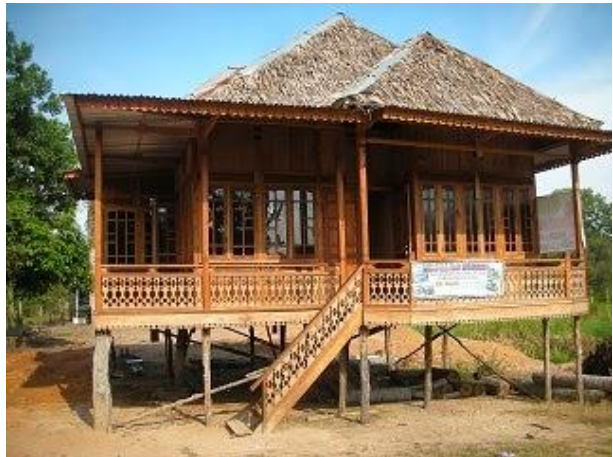

Gambar 20. Rumah Bongkar Pasang Sumber: Ogan Ilirku, 2014 


\section{Tipologi Rumah Vernakular Sumatera Selatan}

Davis (2006) menyatakan bahwa pada umumnya rumah di Sumatera memiliki atap yang tinggi dengan lantai utama terangkat dari tanah dan beranda menjorok maju. Atap yang tinggi diduga dirancang agar air dapat segera turun karena atap tinggi mengakibatkan kemiringan atap yang curam pula untuk menghindari penggunaan lahan yang terlalu luas. Selain itu, atap tinggi diperlukan untuk sirkulasi udara yang lebih baik. Bentuk atap sendiri dipandang sebagai bentuk simbolik dari perahu yang membawa leluhur penduduk ke pulau Sumatera. Walau begitu, hipotesis ini tidak dapat diterima karena leluhur suku-suku di Sumatera lebih mungkin datang dalam jalan darat ketika Paparan Sunda masih terbentuk, ketimbang lewat laut seperti rupa muka bumi saat ini. Sungguh demikian, jika rumah dibuat pada periode sejarah, hal ini dapat diterima terkait migrasi penduduk menggunakan sungai (Schefold, R., Nas, P., \& Domenig, G., 2004). Tetapi terdapat bukti kalau rumah tipe Melayu dengan atap pelana telah ada di Sumatera Selatan sekitar abad ke-7 Masehi (Schefold, R.,
Nas, P., \& Domenig, G., 2004). Begitu pula, Schefold et al (Schefold, R., Nas, P., \& Domenig, G., 2004) berargumen bahwa sebenarnya, asosiasi nautikal dari rumah vernakular Sumatera Selatan sebenarnya terdapat pada bentuk lantai ketimbang atap.

Walaupun studi ini tidak meninjau secara mendalam keseluruhan dari 29 suku asal Sumatera Selatan dan suku-suku sekitarnya dalam aspek arsitektur vernakular, sejumlah kesimpulan tipologis mengenai rumah vernakular Sumatera Selatan dapat ditarik.

1. Terdapat 18 tipe rumah yang ditemukan di Sumatera Selatan. Dari 18 tipe ini, enam memiliki atap limas, sembilan atap pelana, dan tiga atap perisai. Bentuk optimal untuk meneruskan air hujan adalah bentuk pelana dan perisai karena meneruskan langsung air hujan dari puncak rumah. Adanya tipe limas yang merupakan tipe yang cukup banyak menentang pandangan umum kalau rumahrumah Sumatera memiliki atap yang dioptimalkan untuk meneruskan air hujan turun, karena atap limas memiliki bagian bawah yang lebih landau (Tabel 2).

Tabel 2. Tipe Rumah berdasarkan Tipe Atap

\begin{tabular}{cll}
\hline No & Nama Rumah & Tipe Atap \\
\hline 1 & Pesirah & Limas \\
2 & Limas & Limas \\
3 & Lintang & Limas \\
4 & Tua Bubungan Lima & Limas \\
5 & Lamban Tuha & Limas \\
6 & Gudang & Limas \\
7 & Panggung Air & Pelana \\
8 & Lom & Pelana \\
9 & Perahu Kolek & Pelana \\
10 & Rakit & Pelana \\
11 & Minanga & Pelana \\
12 & Baghi & Pelana \\
13 & Godong & Pelana \\
14 & Tunggu Tubang & Pelana \\
15 & Potong Jang & Pelana \\
16 & Bongkar Pasang & Perisai \\
17 & Komering & Perisai \\
18 & Rakit Pedamaran & Perisai \\
\hline
\end{tabular}

Menariknya, tipe-tipe atap rumah ini tidak terlokalisasi di satu titik. Rumah-rumah limas memang ditemukan di sepanjang lembah di tengah Sumatera Selatan (DAS Musi) dari Palembang sampai Lematang yang menerus dari timur ke barat, tetapi rumah dengan atap limas juga ditemukan di Musi Banyuasin di utara dan Lintang di pedalaman barat hingga ke Lambak di Bengkulu dan Ranau di barat daya. Sementara itu rumah tipe perisai banyak di kawasan timur laut. Rumah dengan tipe atap pelana banyak ditemukan di kawasan pedalaman barat, tetapi juga digunakan pada rumah rakit dan perahu kolek yang memiliki mobilisasi tinggi di sepanjang sungai dan 
laut, maupun rumah panggung air di pesisir sungai dan laut, serta rumah Lom di kawasan Bangka. Hal ini mencerminkan dinamika mobilisasi etnik yang tinggi di Sumatera Selatan (Schefold, R., Nas, P., \& Domenig, G., 2004) (Gambar 21). Karenanya rumahrumah adat dapat saling mengalami akulturasi.

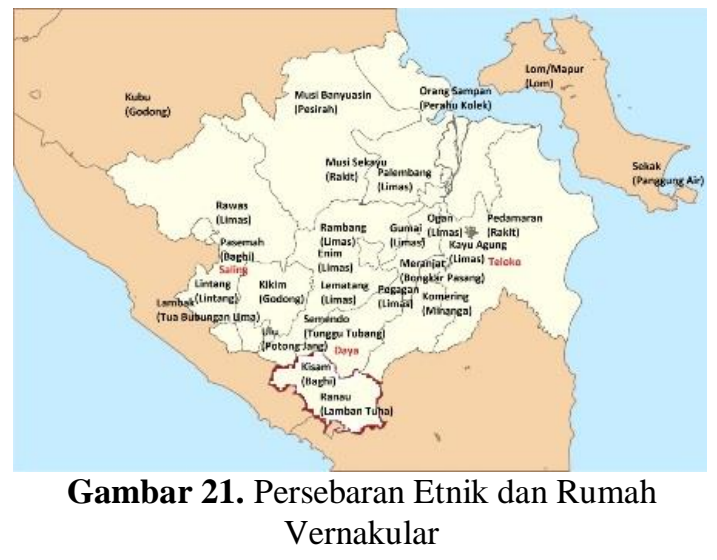

2. Semua rumah memiliki tipologi panggung, kecuali rumah rakit dan perahu kolek yang mengapung di atas sungai. Tipe ini disebabkan kebutuhan untuk menyelamatkan diri dari binatang buas atau banjir pada tanah rawa di Sumatera Selatan. Ketika hal ini tidak lagi terlalu dipermasalahkan, bagian kolong ini dapat digunakan sebagai tempat penyimpanan. Risiko gempa dikompensasi dengan model penyusunan tiang penyangga panggung yang dirancang khusus.

3. Bersama dengan tipe yang hampir semuanya panggung, tipe dinding juga bervariasi bahkan untuk satu etnik. Hal ini dapat disebabkan kekerabatan yang sebenarnya terlalu dekat dari suku-suku yang ada. Karenanya, walau Schefold et al (Schefold, R., Nas, P., \& Domenig, G., 2004) berpendapat bahwa provinsi Sumatera Selatan mungkin merupakan provinsi paling kaya dalam keanekaragaman etnik, hal ini tidak terekam pada keanekaragaman yang mencolok pada tipologi rumah, kecuali pada bentuk atap.

Dalam konteks urbanisme baru, rumahrumah ini kemudian memungkinkan pembentukan pusat-pusat kota berbasis vernakular. Sejumlah implikasi yang dapat diambil antara lain:
1. Masyarakat dapat dilayani di pusat permukiman dengan fasilitas yang dibentuk menyerupai arsitektur vernakular terkait, khususnya Puskesmas, sekolah, dan rumah ibadah. Hal ini pada awalnya dapat dilakukan dengan semata mengubah bentuk atap, dengan proporsi yang sesuai, berdasarkan daerah masing-masing. Dengan cara ini, masyarakat mendapatkan identitas yang lebih kuat dan memungkinkan mereka lebih merasa akrab dengan fasilitas publik yang ada, terlebih jika eksterior bawah maupun interior diadaptasi sesuai arsitektur vernakular terkait.

2. Rumah-rumah bergaya vernakular baru dapat disisipkan di antara bangunan-bangunan permanen yang telah ada, kapanpun memungkinkan, setidaknya pada bentuk atap. Hal ini akan menciptakan pencampuran tipe rumah yang menghilangkan kesan modernisme di perkotaan. Lebih dari itu, trotoar dapat diperluas dan menghilangkan garasi yang ada di depan rumah, dengan menggantinya dengan garasi di bawah rumah bagi rumah bergaya vernakuler berbentuk panggung.

3. Relasi antara kelompok kaya dan kurang mampu dapat dijembatani salah satunya dengan desain rumah bergaya vernakular, baik rumah orang kaya ataupun rumah orang kurang mampu. Dengan adanya jalan samping yang lebar dan kosong dari PKL, penghuni rumah vernakular yang kaya dapat mengundang yang kurang mampu untuk melihat-lihat, sementara gaya vernakular orang kurang mampu dapat mendorong rasa ketertarikan dan komunikasi orang kaya dengan orang kurang mampu.

\section{KESIMPULAN}

Sebagai kesimpulan, diketahui bahwa dari total 31 suku yang diperiksa, diperoleh 18 jenis rumah vernakular, terbagi dalam tiga kelompok berdasarkan tipe atap. Selanjutnya, telah dibuat sejumlah rekomendasi implementasi tipologi ini pada urbanisme baru di Sumatera Selatan sehingga memungkinkan nilai-nilai publik/sosial dapat diutamakan kembali, sebagaimana hakikat masyarakat kolektivis Indonesia, ketimbang nilai-nilai privasi yang diunggulkan dalam paradigma modernisme. 


\section{Daftar Pustaka}

Alimansyur, M. Ma'moen Abdullah, Djumiran, Zainal Makmur, Tabrani Sidin (1985) Arsitektur Tradisional daerah Sumatera Selatan. Proyek Inventarisasi Kebudayaan Daerah Direktorat Sejarah dan Nilai Tradisional Departemen Pendidikan dan Kebudayaan.

Amin, Z. (2013) Rumah Rakit Hemat Energi Di Sungai Musi Palembang: Analisa dengan program Ecotect 5.2. Journal of Architecture and Wetland Environment Studies, 1(1).

Andaya, B. W. (2006) Oceans unbounded: Transversing Asia across "area studies". The Journal of Asian Studies, 65 (04), 669-690.

Anonim. (2010) Mengenal Kehidupan Suku Anak

Dalam. http://jejehhati.blogspot.co.id/2010/03/me ngenal-kehidupan-suku-anak-dalam.html

Anonim (2014) Rumah Adat yang ada di Propinsi Sumatera Selatan. http://www.hdesignideas.com/2014/10/ru mah-adat-yang-ada-di-propinsi.html.

Ardiansyah, S.T. (2011) Makna dan Identitas Ruang Rumah Limas Palembang. Prosiding Simposium Alam Bina Serantau, Denpasar, Bali, Indonesia, hal. 218-239

Bettencourt, L. M. (2013) The kind of problem a city is. Die Stadt Entschlusseln: Wie Echtzeitdaten Den Urbanismus Verandern: Wie Echtzeitdaten den Urbanismus verändern, 175-187.

Bohl, C. C. (2000) New urbanism and the city: Potential applications and implications for distressed inner-city neighborhoods. Housing Policy Debate, 11(4), 761-801.

BPS (2011) Kewarganegaraan, Suku Bangsa, Agama, dan Bahasa Sehari-Hari Penduduk Indonesia: Hasil Sensus Penduduk 2010. Jakarta: BPS.

Davis, H. (2006) The culture of building. Oxford University Press.
Diem, A.F. (2004) Pengaruh Orientasi Bangunan terhadap Pengkondisian Thermal Dalam Ruangan pada Rumah Rakit Palembang. Tesis. Universitas Diponegoro

Ellis, C. (2002) The new urbanism: Critiques and rebuttals. Journal of Urban Design, 7(3), 261-291.

Ercoskun, O. Y. (2009) Green urban planning and design for smarter communities. Organizational Communication and Sustainable Development: ICTs for Mobility: ICTs for Mobility, 41.

Fransiska, W., Setiawan, W. (2006) Rumah Lamban Tuha: Palembang, Sumatera Selatan. Indonesia Design, 3(14), 104107

Glassie, H. (1990) Architects, vernacular traditions, and society. Traditional Dwellings and Settlements Review, 9-21.

Groat, L. N., \& Wang, D. (2013) Architectural research methods. John Wiley \& Sons.

Harian Rakyat Bengkulu. 5 Februari 2015. Rumah Tua Bubungan Lima yang Nyaris Punah Sudah Ada Sejak Tahun 1916, Bubungan Ditulis Doa-Doa.

Hidayat, H. (2014) Konteks Ekologi Kota Tepian Sungai dalam Perspektif Lokalitas Bahan Bangunan. Architecture Event 2014: Membangun Karakter Kota Berbasis Lokalitas

Hipp, J. (2010) What is the 'neighbourhood' in neighbourhood satisfaction? Comparing the effects of structural characteristics measured at the micro-neighbourhood and tract levels. Urban Studies, 47 (12), 25172536.

Jacoby, S. (2013) The reasoning of architecture: type and the problem of historicity (Doctoral dissertation, Berlin, Technische Universtität Berlin, Diss., 2013). 
Ikhae (2010). Panggil Saja Kami Orang Sawang. http://travellere.blogspot.co.id/2011/01/pa nggil-saja-kami-orang-sawang.html.

Kaskus. (2015) Suku-Suku yang ada di Sumatera Selatan. https://www.kaskus.co.id/thread/54f02a3 20e8b468b4f00000a/suku-suku-yang-adadi-sumatera-selatan/

Lensa Berita (13 November 2015) Mengenal Rumah Tunggu Tubang Semende.

Louw, M. P. (2012) The new urbanism and new ruralism frameworks as potential tools for sustainable rural development in South Africa (Doctoral dissertation, Stellenbosch: Stellenbosch University).

Majid, I (2008) Rumah Panggung Khas Empat Lawang. http://forumlintangempatlawang.blogspot. com/2008/03/rumah-panggung-khasempat-lawang.html\#ixzz4TV96d4RN.

Mariendo, A.J. (2015) Redesain 3-4 Ulu Palembang Sebagai Kawasan Wisata. Tesis. Universitas Sriwijaya

Murod, C. dkk. (2002) Langgam Arsitektur Rumah Tradisional Daerah Minanga di Kabupaten Ogan Komering Ulu. Universitas Sriwijaya.

Prasetijo, A. (2013) Konsep "Rumah" bagi Orang Rimba. http://etnobudaya.net/2013/12/30/konseprumah-bagi-orang-rimbal

Prijotomo, J. (1996) When West Meets East: One Century of Architecture in Indonesia (1890s-1990s). Architronic, 5(3), 04a.

Rinaldi, Z., Purwantiasning, A. W., \& Nur'aini, R. D. (2015) Analisa Konstruksi Tahan Gempa Rumah Tradisional Suku Besemah Di Kota Pagaralam Sumatera Selatan. Prosiding Semnastek.
Rumah Perumahan (2016) Desain Bentuk Rumah Adat Empat Lawang dan Penjelasannya. http://www.rumahperumahan.com/2016/0 8/desain-bentuk-rumah-adat-empatlawang.html.

Ogan Ilirku (2014). Mengenal Suku Penesak di Ogan Ilir. http://oganilirku.blogspot.co.id/2014/06/ mengenal-suku-penesak-di-ogan-ilir.html

Saganta, J., Imron, A., \& Arif, S. (2014). Rumah Ulu Pada Masyarakat Adat Komering Di Ogan Komering Ulu Timur.Pesagi (Jurnal Pendidikan dan Penelitian Sejarah), 2(4).

Santun, D. I. M., Murni, M., \& Supriyanto, S. (2010) Iliran dan Uluan: Dikotomi dan Dinamika dalam Sejarah Kultural Palembang. Palembang: Eja Publisher.

Schefold, R., Nas, P., \& Domenig, G. (Eds.). (2004). Indonesian Houses: Tradition and transformation in vernacular architecture. NUS Press.

Schefold, R. (2014) Indonesian Houses: Volume 2: Survey of Vernacular Architecture in Western Indonesia (Vol. 2). Brill.

Siswanto, A., Salim, A. S. B. S., Dahlan, N. D., \& Hariza, A. (2011) Architectural And Physical Characteristics Of Indigenous Limas'houses In South Sumatra. Universiti Putra Malaysia.

Siswanto, A., Salim, A. S. B. S., Dahlan, N. D., \& Hariza, A. (2013). The Phenomenology of Lamban Tuha: The Local Wisdom of South Sumatra Traditional Architecture. International Transaction Journal of Engineering, Management, \& Applied Sciences \& Technologies, 4(2), 157-170.

Sumintardia, D (1974) Traditional Housing in Indonesia: Palembang-South Sumatra.

Tribun News. (2014) Balai Adat Suku Lom Belinyu Tempat Diskusi Warga. http://www.tribunnews.com/regional/201 4/04/16/balai-adat-suku-lom-belinyutempat-diskusi-warga. 
Triyuly, W., Sri Desfita, Y., \& Ade Tria, J. (2013) Identifikasi Rumah Tradisional di Lorong Firma Kawasan 3-4 Ulu, Palembang. Prosiding Temu Ilmiah Ikatan Peneliti Lingkungan Binaan 2013, F-17.

Undang-undang RI No 28 tahun 2002 Tentang Bangunan Gedung.

Utami, E (2016) Jalan-Jalan ke Kecamatan Pedamaran.

http://kayuagungradio.com/jalan-jalan-kekecamatan-pedamaran/

Vau G. (2016). Upacara Adat Nujuh Jerami, Suku Lom/Mapur. http://www.kompasiana.com/vaug/upacara-adat-nujuh-jerami-suku-lommapurbangka_571178f13cafbd18048b456f

Zulfikri (2004) Efektivitas bukaan Pintu pada Rumah Tradisional Limas Palembang terhadap Pengendalian temperatur Udara dalam Ruangan. Tesis. Universitas Diponegoro. 